\title{
REPRESENTATION OF THE ANCIENT MYTH ABOUT HYPERION IN MODERN GRAPHIC LITERATURE
}

\author{
Evelina Luchko \\ Postgraduate Student, Oles Honchar Dnipro National University, Ukraine \\ e-mail: evelina.shiyan@gmail.com, orcid.org/0000-0002-0979-9723
}

\section{Summary}

The article aims to investigate the peculiarities of the new myth about Hyperion embodied in Marvel's periodical graphic literature in comparison with the tradition of literary interpretations of the traditional Titanomachy myth. The article considers graphic literature to be a developing intermedial genre gaining popularity among readers, although underestimated by scholars. The interconnections between the comics and romantic and postmodern literature are studied. It is also highlighted that borrowings from European literature are a characteristic feature of American cultural tradition due to the lack of its own ancient basis. The article also traces the influence of modern comic tradition on reconsidering the ancient story about a rebellious titan. Functioning of superheroes as role models for the youth, the tendency for comic authors to depict conventional characters being close to modern realia and understandable for mass readers comes into the focus of the research. Thus, a new myth about Hyperion of the XXI century is created, in which the main character becomes a combination of such iconic images as Prometheus and Superman, reconsidered in the way making it possible for the image to serve the agenda and ideology.

Keywords: comics, new myth, titan, Marcus Milton, Avengers, Marvel, mass reader

\section{DOI: https://doi.org/10.23856/4409}

\section{Introduction}

Comics, or graphic novels, are a relatively new genre of art, although its roots go deep into prehistoric times. Images with inscriptions as a means of communication date back to ancient Egypt. Graphic novel, which belongs to the postmodern genre, has recently become widespread because it helps readers understand the story very easily.

In today's world, graphic novels and comics are very common. Thus, according to the Statista website, $37 \%$ of the adult population of the United States at least sometimes read comics (compared to 65\% of printed books readers) in 2018 (Watson, 2020). Moreover, graphic novels are increasingly being screened and turned into games, which strengthens their position in the media space.

As the current media interest continues to focus on comics and related series, the popularity of the graphic novel will continue to grow. The time has come for the general public acceptance of graphic novels, which are taking their place as "real" literature. However, for the scientific perception of graphic literature there are still not enough critical works on this topic. Thus, it is the combination of the readers' interest and lack of research on the topic that determines the relevance of the presented work.

This study is the first scientific attempt to examine a series of comics about superhero Hyperion by Marvel from a literary point of view and examine its relationships with the tradition of literary interpretations of the Hyperion image from ancient times to the twentieth century. 
The purpose of this article is to investigate the peculiarities of the image of Hyperion in modern graphic literature. It involves a number of tasks: to investigate the level of research on graphic literature; to compare the image of Hyperion in graphic literature and in the existing literary tradition; to investigate the influence of comic tradition on the image of Hyperion by Marvel; to highlight the unique features of the hero's image, characteristic only of graphic literature.

The research methodology is complex and includes elements of comparative, literaryhistorical methods; motive analysis is also used. The use of the mythopoetic method allows to identify the basic images, motives and plots. Semiotical and myth-critical approaches have become auxiliary methods. The deep symbolism, intertextuality and metatextuality of the studied texts determine the use of the hermeneutic method. When comparing graphic literature with traditional interpretations of myth, there is a need to turn to the historical and cultural approach, that is why the latest research in the field of comparative studies are used.

\section{Intermedial interpretations of Hyperion's image}

The ancient Greek myth of Hyperion, which is a part of the series "Titanomachy", is dedicated to the struggle of the Uranian titans and the Olympian gods. According to the legend, a new generation of Olympian gods rebelled against the old gods, the powerful titans, in order to overthrow them and rule the universe. The leader of the Titans in this struggle was Cronus - the former supreme god. On his side, among others, fought the titan Hyperion, the son of Cronus and Gaia. His name means "the one who goes high". The Olympians won the war, after which the Titans were overthrown to Tartarus. Others were subverted by the arrows of the Sun God Apollo, the son of Zeus, or murdered by heroic demigods.

The plot of "Titanomachy" and the image of Hyperion became the basis for many works of art and literature of the Romantic era. Among them there is the work of German romantic author Friedrich Hölderlin "Hyperion" (Hölderlin, 1797), which was the first projection of the myth about Hyperion on European literature, reflecting the moods of his time; two unfinished poems by John Keats "Hyperion" (Keats, 1818) and "The Fall of Hyperion" (Keats, 1819), as well as a novel by American writer Henry Longfellow "Hyperion" (Longfellow, 1839). The romantics' appeal to the same myth was due to the attractiveness of Hyperion's image, which embodied a free rebellious beginning and an indomitable spirit.

Hölderlin in "Hyperion" epistolary novel (1797), through the events in Greece in the VIII century, reflected upon the problems which were typical of Germany. To characterize the protagonist of the novel - a young man called Hyperion - the most important thing is that he is a fighter for personal happiness and for Greece. Therefore, it is a certain projection of the mythological titan on the modernity of the author. For Hölderlin and his Hyperion, the gap between dream and reality remains insurmountable, which is characteristic of European romanticism.

English poet J. Keats in his poem "Hyperion" (1818) and its sequel "The Fall of Hyperion" (1819) also reinvents the traditional myth in a romantic way, focusing on the image of a mythological hero - the ideological and active leader of the Titans, who inspires them to fight. Changing the old with the new and the better is the central motif of Keats's poem, and the struggle of the Titans becomes an illustration of the grand idea of historical progress. Keats believes that it is necessary for humanity to evolve to achieve the ideal of absolute beauty and harmony. He also advocates the idea that poets are the closest to this ideal.

Henry Longfellow was the first American writer who interpreted the myth about Hyperion. His novel "Hyperion" (1839) also represents a romantic interpretation of the myth. It shares such features of a romantic story as personalising the text, trend to include extracts from 
poetic works in order to highlight the author's point of view, paying much attention to depicting nature, emphasising the leading role of poets in society and romanticising the idea of struggle. Longfellow's novel is partly autobiographical. So, we can say that the image of the main hero Paul Fleming - is partly the image of Longfellow himself, moreover, the protagonist transmits the author's ideas concerning creativity, life and death, divine forces.

"Hyperion" (1989) by American postmodernist D. Simmons (Simmons, 1991), like Longfellow's novel, is a new myth. But this is a typically postmodern piece of literature. This is a novel, containing such features characteristic to postmodern prose as intertextuality, double coding, genre syncretism, pastiche, author's playing literature, irony, fragmentality and epistemological uncertainty because of the crisis of faith in science and technical progress. The novel is connected to mythology on the level of text and problematics. But the author's outlook shifts to scientific-mythological, as his mythological prospect of the world is completed with scientific details taken from physics, biology and astronomy. This is a trait, typical to postmodern texts, as these days not intuition, as it was in romantic era, but facts help us understand the world.

In the end of the twentieth century, the image of Hyperion entered the intermedial space and now functions not only in literature, but also in comics, computer games and their codes, and in the cinema.

The most common situation in mass media is when the name 'Hyperion' is used for fictional spaceships, for example in The Island at the Top of the World (1974) and in a series of science fiction novels by Japanese writer Yoshiki Tanaka (1982-1987) and their anime adaptation (1988-1997) Legend of the Galactic Heroes, in the novel Skybreaker (2005) by Canadian author Kenneth Oppel (born 1967) and in the fantasy series Skyland (2005-2007), in the series Star Craft (1998-2017), Eve Online (2013 - present), Mass Effect Andromeda (2017), Einhändler (1997), Hokai Impact 3rd (2016). Hyperion is also the name of the weapon corporation in the games of the Borderlands series (2009-2019) and a type of futuristic weapon from the game Final Fantasy VIII (1999). In the series Angel (1999) and Once upon a time (2011-2018) Hyperion is the name of the rescue base and the mountain. In the poem by Mihai Eminescu, a Moldavian-Romanian poet of the late 19th century. - "Luceafarul" (1983) is the name of a selfaware star, and in the anime Gekiganger III (1998), it is the name: Emperor Hyperion. The history of interpretations of the myth of Hyperion was continued at the beginning of the XXI century. Among them there is the kaiju novel by the American writer Jeremy Robinson "Project Hyperion" (1974). Another notable phenomenon is the intermedial space of the Warhammer universe, which includes board role-playing codes, several computer games, and several dozen novels. One of the heroes of this universe is the gray knight Hyperion - a famous fighter for the Emperor, who is the protagonist of the novels by Aaron Dembski-Bowden (born 1980) "Gift of the Emperor" and Dan Abnett (born 1965) "Inquisitor Ravenor".

That is, the image of Hyperion has become significant precisely for the development of the genre of science fiction. Thus, we can say that the cultural and symbolic halo surrounding the image of Hyperion is very popular today and it is used in various spheres of human activity in order to evoke certain associations with the mighty titan. But the most popular interpretation of Hyperion's image was created in the XXI century by Marvel comics company, which turned the mythical titan into a superhero.

\section{Comics in literary theory}

For many scholars, the word comics used to refer to a periodical that is intended for younger readers and does not carry much hidden sense. However, in the 80 s of the twentieth century 
there happened some significant shifts, which, according to American scientist F. Jameson, are primarily manifested in "the effacement in them of the older (essentially high-modernist) frontier between high culture and so-called mass or commercial culture, and the emergence of new kinds of texts infused with the forms, categories and contents of that very Culture Industry" (Jameson, 2008). In 1985 graphic novel "Watchmen" by DC was published by Alan Moore and Dave Gibbons. This event started an era of serious comic book literature and "Watchmen" soon became truly iconic. It led to the revival of comic art, the development of adult readership and an unsurpassed period of artistic experimentation and growth. Graphic novels have become increasingly popular in the United States over the past decade and a half. Now the market for related comic book collections continues to grow, which is often referred to as an "indication of the aesthetic and literary development of the comic art environment in the United States" (Couch 2000).

Research literature on comics has only recently begun to emerge in the past few decades. It was not until the 1970s that the field of comic studies first emerged as an academic discipline, due to a somewhat superficial and frivolous attitude towards the genre (Murray, 2017).

In 1985, Will Eisner, one of the founders of comics research, used the term 'sequential art' to describe the phenomenon of graphic literature in his book "Comics and Sequential Art" (Eisner, 1985). The deepest analysis of the comic art publications is McCloud's "Understanding Comics" and "Reinventing Comics". The author understands comics as "juxtaposed... images in a deliberate sequence" (McCloud, 1992: 9). Another thorough research is Lefevre's article, emphasizing the heterogeneity of the comic genre (Lefevre, 2005).

In Europe, it has become traditional to look at comics through the prism of the theory of semiotics (Pierre Freno-Druel, Alain Ray, Jan Baetens). In the United States, several academic journals publish articles on text-image relations in comics (Richard Watts, David Carrier). In recent decades, there has been a rapid growth in empirical and experimental studies of comics as visual narratives. The leading researcher in this field is American scholar Neil Cohn.

\section{Hyperion as a superhero in comics}

The most notable event in the modern history of Hyperion myth interpretations was the appearance of this character in the dimension of comics, when in 2013 the Marvel studio released a series of graphic novels, or comics, about superhero Hyperion.

So, Hyperion first appeared in the 5th issue of the Avengers comic (Hickman \& Spenser, 2013), but he immediately became so popular that the character received several of his own "Hyperion" series, and also appeared in such series as "Squadron Supreme".

The protagonist Hyperion, Marcus Milton in his past as an ordinary human, embodies a huge layer of allusions and reminiscences from the world culture. The most significant of these, is appealing to the ancient Greek Titanomachy. In "Avengers" the protagonist is the last survivor of the Eternal race, which, according to Marvel comics, gave birth to the Titans. So, as in the ancient myth, Hyperion is a titanic figure. Like any superhero, Hyperion has some unique abilities: he can move fast, fly, survive in space, his body regenerates almost instantly, he is so physically strong that he can hold two planets, and lasers come out of his eyes (Hickman \& Spenser, 2013), which refers to the image of the ancient titan who controlled sunlight.

But Hyperion, to whom the comics refer, as in the case of romantic poets' interpretations, is a collective image. It has more features of Helios, such as his transitional essence, the middle position between the two generations, the attempt to serve the new world. Other features which his image shares with the ancient and romantic interpretations are titanicity, greatness, the ability to fight and rebel. 
Such majestic figures are quite typical of American superhero comics. Superheroes are often based on mythological characters, such as the thunder god Thor in Norse mythology or the Wonder Woman, based on the legends about Amazon warriors. This borrowing is the example of a traditional American culture's appeal to the European heritage due to the lack of its own ancient history and culture. The familiar traditional images are processed in the way necessary for American ideology and adapted to the realia of a particular time. Thus, these characters immediately gain popularity among the readers and are a great tool for conveying the author's, as well as government's, thoughts.

As for the features making comic Hyperion close to Dan Simmons's postmodern novel, they are targeting on the mass reader, abundance of allusions and reminiscences, focusing on modern scientific ideas and trends. Both interpretations use the experience of previous Hyperion versions and play with the reader using this. Moreover, both "Hyperions" are close to modern realia and worldview.

In the new millennium the image of Hyperion has been brought closer to a common man so that the reader could associate themself with the hero. Marcus was raised on one of the planets of Marvel's multiverse, his parents were ordinary people without superpowers, who instilled in him honesty, diligence, responsibility and a sense of justice. Hyperion often mentions his father's advice, which became his life principle: "Truth without compromise. Thought without error. All things for the betterment of the whole" (Wendig, 2016). The moral imperatives of the protagonist run through all the issues of comics: "To be given, is to know what it is to give, we know virtue because while we may not suffer, we can hear the suffering of those around us. The duties I was in charge with were more important. They were Titans and Gods and mortals doing immortal acts" (Wendig, 2016). Hyperion's missions also tend to become more mundane, which an ordinary person can try on themself. He rescues the girl from bandits, helps alien orphans set up a shelter and teaches children everything he knows. "So, this is the world, and our children in it. We either choose to be crippled by that fear, or we raise the innocent to be steadfast, we teach them hope... And then believe it will be enough," he says (Hickman \& Spenser, 2013). He is the kind of a titan that a reader finds it easy to associates themself with.

Thus, Hyperion realizes both his belonging to the race of the Titans and his responsibility for humans' life. He finds his mission in making the lives of ordinary mortals better. This is considered to be a parallel with the image of another ancient titan - Prometheus, whose figure is perhaps the most popular titanic image of mass culture. The ancient titan also felt obliged to share knowledge and skills with people, even at the cost of his own life.

In addition to borrowings from Titanomachy, there is a significant influence of the comic book hero Superman on Hyperion's image. Superman is one of the first superheroes of the DC studio, he is probably the most popular hero of the twentieth century, whose image appears not only in comics, but also in many movies, TV series, cartoons, books, songs. He has undoubtedly influenced the entire comics industry and has become the prototype for many generations of superheroes. Superman and Hyperion have not only the same abilities, such as flight, strength, the ability to emit lasers from the eyes, but also a similar moral code, based on high values, self-esteem and a desire to help people. They are created as a model for new generations what a young American and a citizen should be like. Thus, modern comics, like classical literature of its time, sets high moral standards for the reader, but speak a language understandable to modern youth. But Superman's image used to be rather idealistic: he has no doubt, no weaknesses, he does not feel anger nor strives for revenge, which makes it hard for readers to draw parallels between the superhero's reality and their life. As for Hyperion, he is quite true to life, with his own regrets and vulnerabilities, he does not always win or shows mercy when needed, he is 
able to experience normal human feelings and affections. Such a mundane hero communicates the author's ideas better than an idealistic template and makes ordinary people believe that they are also capable of titanic deeds.

The Hyperion series, as well as most comic series by Marvel or DC, can be considered as examples of new myth-creation of the metamodern information era. Such new myths embody the features of ancient legends, classical and postmodern literature, other examples of graphic literature, science, cinema and everyday life, processing it all into a multidimensional unity. Besides, they take into consideration the allegiances and opinions of the mass reader as well as the agenda. Thus, comics combine scientific worldview, making it topical, with the mythological, making it easier to believe, adding there some specific aspects of post-industrial outlook, and enclose them into effortlessly-understandable form which gives such kind of literature the opportunity to influence a wide circle of readers.

\section{Conclusions}

To sum up, the image of titan Hyperion represented in graphic literature by Marvel is a modernized and adjusted to topical problems version of an ancient character. The Hyperion of nowadays combines not only the traits of Hyperion and Helios, whose name he obtains, but also some features of Prometheus, the titan who did most of all the titans for the humanity. The superhero also shares the traits characteristic of romantic interpretations of the image, such as great mission, outstanding abilities, and willing to change the world for the better. As for the common features with postmodern interpretations of the myth, they are characterized by scientific worldview, skepticism of the grandeur of the titans and their ways, using modern material, understandable for a wide circle of readers. The comic series also shares some peculiarities with the image of Superman, that has become cultic in XX century mass culture. These are not only similar superpowers, but also high moral values of both characters and their aim to serve as a role model for public. However, the comic image of Hyperion has some unique qualities, making it close and understandable for readers, such as vulnerability, affections and doubts. Due to such 'humanization' it becomes easier to feel the empathy and associate oneself with the hero, which leads to higher sense of morality and willing to improve the world among the youth. Nevertheless, such influence on readers can be used by comics' creators for the means of propaganda and shaping opinions in the way appropriate for authorities.

To conclude, the comic series about Hyperion are a new myth which is a typical product of the metamodern information era. It is a multidimensional unity which embodies all the previous cultural experience as well as modern trends, and influences as many readers as none of the traditional myths could before.

In general, the scientific research of graphic literature seems insufficient at this stage, and needs further development and improvement. When it comes to the comparison of mythopoetics in comics and in classic or postmodern literature, there is a lack of such research both in Ukrainian and foreign studies.

The prospects for further research are to study the transformation of other ancient and traditional images in modern graphic literature and trace the tendencies characteristic of comics' mythopoetics and the principles of myth creation within the visual narrative genre. 


\section{References}

Couch C. (2000). The Publication and Formats of Comics, Graphic Novels, and Tankobon. Retreived from http://www.imageandnarrative.be/inarchive/narratology/chriscouch.htm.

Eisner W. (1985). Comics and Sequential Art. New York: Poorhouse Press.

Hickman J. \& Spenser N. (2013). Avengers. Vol. 5 \#12. A. Alonso (Ed.). Marvel. Retrieved from https://readcomiconline.li/Comic/Avengers-2013/Issue-12?id=13585.

Hölderlin F. (1797). Hyperion oder Der Eremit in Griechenland. Anaconda.

Jameson F. (1991). Postmodernism, or, the Cultural Logic of Late Capitalism. Retrieved from https://newleftreview.org/issues/i146/articles/fredric-jameson-postmodernism-or-the-cultural-logic-of-late-capitalism.

Keats J. (1818). Hyperion. Retrieved from http://classiclit.about.com/library/bl-etexts/jkeats/ bl-jkeats-hyp.htm

Keats J. (1819). The Fall of Hyperion. Retrieved from http://www.john-keats.com/gedichte/ the fall_of_hyperion.htm.

Lefevre, Pascal (2005). The Importance of Being 'Published', a Comparative Study of Different Comics Formats. Retrieved from https://www.academia.edu/660771/The_Importance_of_ Being_Published_A_Comparative_Study_of_Different_Comics_Formats.

Longfellow H. (1839) Retrieved from http://www.general-ebooks.com/book/74211230-hyperion. McCloud, S. (1992). Understanding Comics. New York: Harper Collins.

Murray C. (2017) Graphic novel. Retrieved from https://www.britannica.com/art/graphic-novel.

Simmons D. (1991). Hyperion. London: Headline Book Publishing.

Watson E. (2020). Frequency of reading comics in the US 2018. Statista website. Retrieved from https://www.statista.com/statistics/943111/comic-book-reading-frequency-us/.

Wendig Ch. (2016). Hyperion. Vol. 2 \#1-6. Alonso A. (Ed.). Marvel. Retrieved from https:// readcomiconline.li/Comic/Hyperion-2016/Issue-1?id=45930. 